\title{
Impact of Certified Training Programs on Health Professionals' Levels of Organizational Commitment
}

\author{
Ebru Buğra ${ }^{1}$ \\ Istanbul Anatolian South Region Public Hospitals Association
}

\begin{abstract}
Rapid improvements in the health sector in recent years have made changes in health institutions an obligation. The only way an institution can continue to survice in such changing conditions is by investingment in health insitutions most important resource, the human element. The existence of employees who not only adopt the goals and values of the organization for which they work, but who are highly committed and willing to continue working in the organization enables an organization to survive and gain power in increasingly competitive conditions. This study is a quantitative research to analyze the impact of Certified Training Programs on Organizational Commitment by revealing the connection between Certified Training Programs and employees' levels of Organizational Commitment. The universe of the study consists of employees from the Intensive Care Unit, Emergency Room, Dialysis Unit and Transfusion Center. Data were collected using the survey method and the Organizational Commitment Scale developed by Allen and Meyer.
\end{abstract}

Keywords

Education • Certified Training Program • Organizational commitment

1 Correspondence to: Ebru Buğra, Istanbul Anatolian South Region Public Hospitals Association, Yakacık Maternity and Children State Hospital, Kartal Turkey. Email: ebrubugra@yahoo.com

Citation: Buğra, E. (2016). Impact of certified training programs on health professionals' levels of organizational commitment. Sanitas Magisterium, 2, 5-22. http://dx.doi.org/10.12738/SM.2016.1.0015 
Changing world conditions, developing technology, increasing and spreading information, and developments in economic, social and cultural fields have rendered a change in the health sector a must. The only possibility for health institutions' continued survival in this changing system is by making proper investments in the health sector's most important resource, the human element. In other words, the only way to succeed in such rapid developing conditions of competition is for employees to be trained, efficient, coherent with organizational goals and committed to the organization.

\section{Education}

Education can be described in two ways, one from a broader sense and the other from a more strict sense. When looked at in the broader sense, education can be expressed as "lifelong learning" In this sense, education starts with the child's family, cultivated in the child's specific social environment involving the school period. One the individual starts working, his/her education continues to including his/her profession. In other words, education creates a difference in the skills and behaviors of someone from birth to death with the information gained by one's parents, educational backgrounds and workplace, on the one hand, or by improving oneself, on the other. Thus in a broader sense, education can be described as every single effort made by an individual to change himself. In a stricter sense however, education may be understood as when a business organizes programs to train its employees, such as personnel training programs, and this understanding of educaton can be described in different ways (Deniz, 1999, p. 1).

From a different perspective, education is the whole of educational actions organized by businesses for employees or employee groups in order to aid them in completing the work for which they are or will be responsible more efficiently and successfully, on the one hand, and to broaden employees' professional horizons, to change their rational decision making processes, behaviors attitudes, habits, and understanding in a positive way and to increase their knowledge, manners and skills, on the other (Z. Sabuncuoğlu, 1994, p. 125).

The purpose of education and training activities is to make a positive change in employees' knowledge and behaviors so that they will be better able to do their present and future work. In short, education is the systematic, measurable and manageable phenomenon of organizational change (Koçel, 1999, p. 35).

\section{Education in State Institutions and Organizations}

Two important concepts about education and two types of education are "training" and "improvement." Training includes the education activities conducted for new employees so that they may gain new skills and reach new knowledge and skill levels in regards to what their job requires (Kaynak et al., 2000, p. 170). 
Understanding training in State Institutions and Organizations starts by examining the scope of the "General Regulation on the Training of Probationary Officials" effectuated upon being published in Official Journal no. 18090, dated June 27, 1983 based on the article $55^{\text {th }}$, amended by law no. 2670 of the State Personnel Law. The "General Regulation on the Training of Probationary Officials" was prepared to clearly deligneate training programs for Probationary Officials, periods of training, exams in training, the basics of exam evaluation, and other related subjects (Milli Eğitim Bakanlığı, 1983).

Training basics for institutions conducting in-service training are specified in the In-Service Training Regulation effectuated as per article $214^{\text {th }}$, amended by law no. 1327 of the State Personnel Law no. 657.

Ministry of health in-service education. Another concept about education other than "training" is "improvement." Improvement is the enhancement of existing skills. In other words, improvement is an education activity intended for people who are currently working at a job and who have working experience but who lack the necessary level of knowledge. Although training is done during a specified period of time improvement is a never-ending act without specific time periods or limits (Kaynak et al., 2000, p. 170).

The purpose of the Ministry of Health's In-Service Education Regulation is to train Ministry of Health personnel according to the current conditions and to provide them with the knowledge, skills and attitudes required for their jobs, to increase their efficiency through greater awareness of their activities and manners, and to specify the targets, principles, plans, practices and evaluation procedures and basics of inservice education so as to prepare them for higher duties and other subjects (T.C. Sağlık Bakanlığı, 2009).

Ministry of health certified training programs. Certification programs, an area receving more importance in the recent years, work to approximate every level and phase of business activities so as to establish and instill shared values that are as close to "professional" standards as possible, on the one hand, and to ensure that those individuals who are to conduct these activities hold a certificate showing that they have attained the "knowledge" and "skills" required for this activity (Koçel, 2011, p. 89).

To improve the professional knowledge of health workers and to train a qualified labor force, the Ministry of Health organizes certified education programs. The standards, scope and certification processes for education programs providing information and skills on a specific subject are stated in the "Ministry of Health's Certified Training Regulation” updated on February 4, 2014 (T.C. Sağl1k Bakanlığı, 2014). 


\section{Organizational Commitment}

The survival of any organization is linked to its employees not leaving the organization. However much an organization's employees are committed to the organization, that organization will become stronger. To continue surviving,an organization must seek means to prevent its employees from leaving the organization (Çetin, 2004, p. 90).

\section{Definition of the Organizational Commitment}

Organizational commitment is an indication of harmony between the employee and organization and is of utmost importance. Organizational commitment includes a more active relationship in which employees wish to help the organization of which they are part to be more successful and reach its goals rather than simply having passive loyalty toward the organization. The first person to define organizational commitment, Grusky (1966), defined commitment as the power of connection that an individual feels toward an organization (cited in Mercan, 2006). According to Meyer and Allen, organizational commitment is defined as an employee's psychological approachtoward the organization in which s/he works. Organizational commitment is a concept requiring one to identify with the organization's goals, to assume organizational duties and to feel loyalty toward the organization (Y1ld1z, 2013, p. 879).

In a general sense, organizational commitment can be described as "the durability of the attachment the individual feels towards the organization." Apart from this definition, "It is the identification an individual has with his organization and the level of feeling a part of the organization" (Schermerhorn, Hunt, \& Osborn, 1994, p. 14). And definitions such as "It is the level of identification an individual has with his organization and his willingness to continue as an active member of the organization" (Davis \& Newstrom, 1989, p. 179) are made. In the widely used organizational commitment definition of Mowday, Steers, and Porter, three features of organizational commitment can be seen. These can be defined as;

- Believing in the goals and values of the organization and accepting them

- A willingness to endeavor for the organization's interests and

- To have a strong willingness to remain a member of the organization (Tepe, 2004, p. 37).

\section{Dimensions of Organizational Commitment}

Multiple dimensions of organizational commitment have been researched by researchers. One of the most widely used studies is the three-component model of organizational commitment developed by Allen and Meyer. Allen and Meyer 
suggested that every definition in the literature reflected on one of the three components and described these components. In the current study, the dimensions of organizational commitment will be analyzed according to the three-component model by Allen and Meyer (1990). These dimensions are affective commitment, continuance commitment and normative commitment. In this section, the definitions and features of organizational commitment will be analyzed (Allen \& Meyer, 1990, p. 1).

\section{Affective Commitment}

Affective commitment includes the identification and participation of an individual with his organization. Employees with strong affective commitment choose to stay a part of the organization out of their own will (Allen \& Meyer, 1990, p. 2). Such an employee starts to see himself as a part of the organization. It is necessary for employees to accept organizational purposes and values in order for affective commitment to develop.

Employees with strong affective commitments are willing to help as needed to achieve organizational goals, even though such actions may not be a part of their stated duties. An employee who is affectively committed to their organization does not avoid completing the work of his junior colleagues when needed. For example, if it rains hard enough to cause damage on the roof of the organization, an employee attempting to fix the roof even though it is not his job is an employee affectively committed to his organization (Allen \& Meyer, 1990, p. 16).

Factors affecting affective commitment are as follows (Allen \& Meyer, 1990, p. 17):

- Difficulty of the Job: The fact that the work given to the employee is exciting in nature or requires the employee to strive to complete it.

- Openness about Roles: The fact that the organization openly expresses the expectations that it has of the employee.

- Openness about Goals: The fact that employees are informed about how their specific duties fit into the organization's overall objectives.

- Organization's openness to new ideas: The fact that the organization's executive managers take every new idea from their employees into consideration.

- Commitment to Friends: Establishing close relations between the people working in the organization.

- Organizational Commitment: The fact that the employees trust what the organization says about their plans. 
- Equality: Their being equality among employees.

- Personal Importance: The fact that systems exist which instill in employees the belief that their workcontributes to organizational goals.

- Feedback: Giving information about employees' performance.

- Participation: The fact that employees' participate in the decision making process concerning work load and performance standards.

When the factors affecting affective commitment are taken into consideration, it can be seen that they are connected to employees' psychological state, the qualities of their job and their professional life. They become employees committed to their colleagues and excited about their job, on the one hand, and feel as if they are treated equally in the organization, informed about their performance, receive respect for their new ideas, are aware of the expectations or goals, and participate in the decision making process, on the other. In essense, they become employees committed to their organization with an affective commitment to their organization. These employees identify with their organizations and do not hesitate to make sacrifices for their organizations (Allen \& Meyer, 1990, p. 17).

\section{Continuance Commitment}

In the literature, continuance commitment is also called rational commitment or perceived cost. Continuance commitment includes the commitment based on the losses the employee relates to leaving the organization. Continuance commitment is the commitment where the employee remains part of the organization considering the negativities and costs of leaving the organization. Continuance commitment occurs when an employee thinks that he cannot give up their rights, promotion possibilities or wage or believes that he cannot achieve these anywhere else. If an employee fears the difficulties that he will face when starting a new job or if he does not want to leave the city in which he lives or the social life of which he is part, continuance commitment to their organization will surface. It is possible that the employee will shape his career goals in the organization. An employee who has the possibility of receiving a promotion in a different branch of the organization in a different city might have continuance commitment as well. Employees who have been working in the organization for years feel continuance commitment by staying in the organization. Time and experience spent on the organization would seem as a waste in the event of leaving the organization. Introducing themselves to a new environment and the possibility of having difficulty communicating with new managers creates continuance commitment in employees. According to Allen and Meyer, the factors affecting continuance commitment are as follows (1990, p. 18): 
- Skills. If the employee can transfer his skills from one organization to another and if the employee is beneficial for the other organization.

- Education. If the educational background of the employee is beneficial for other organizations.

- Relocation. If it is difficult to relocate once the employee leaves the organization.

- Individual investment. The fact that the employee has spent time and energy for the organization.

- Retirement pension. The possibility to lose accumulated retirement bonuses in the case that they leave the organization.

- Community. The time the employee has lived in the city.

- Alternatives. The fact that the employee may have difficulty finding a better or more comfortable job after leaving the organization.

When the factors affecting continuance commitment are analyzed, it is found that these factors are determined over the cost of leavingone's job. An employee may continue working for the organization out of their own interest causing him to feel committed to the organization (Allen \& Meyer, 1990, p. 19).

\section{Normative Commitment}

Normative commitment includes the obligation the employee feels to stay in their organization. This obligation is related to the moral emotions and values held by an employee. An employee thinks that the organization deserves him and the commitment that he has made (Penley \& Gould, 1988, p. 45).

Penley and Gould stated that since employees with normative commitment not only accept their organization's goals but are willing to identify with these goals they dedicate themselves to their organization and show high performance (Penley \& Gould, 1988, p. 46).

Employees becomming commited occurs not because they want to, but because they believe that staying in the organization is the moral and right thing to do. Whereas affective commitment includes the expression, "I want to stay with the organization" normative commitment includes the expression, "Imust stay with this organization" (Ínce \& Gül, 2005, p. 41). The difference between normative and continuance commitment is that normative commitment does not depend on costs or losses but on moral feelings. If employees are supported, rewarded or motivated by their managers, they may feel guilty about leaving the organization. Because leaving when the organization is striving to make their lives 
better,employees feel that leaving would waste the organization's efforts. This situation would then make an employee considering leaving to feel guilty about his decision.

Allen and Meyer stated that the life of an employee both before and after having started working in an organization affects the occurrence of normative commitment. They found that whether or not an employee is committed to his organizations with strong personal bonds affects normative commitment naming such an attatchment as the organizational commitment norm (Allen \& Meyer, 1990, p. 18).

Employees' education backgrounds, social lives, working paradigm (whether they work for money or for experience) primary values and both family and community cultures affect the occurrence and development of normative commitment (Allen \& Meyer, 1990, p. 19).

When looking at the reflection of organizational commitment in organizations, employees' connection with their organization can be seen to manifest differently. While some employees want to stay with the organization and work with them, they might also be in need of doing it for a number of personal or external reasons. While the moral values and family cultures of some employees require them to stay with the organization, in time they might want to stay with the organization and feel affective and normative commitment to their organization. All three commitment dimensions can be observed in employees. Employees might feel committed to their organization because they want to feel a sense of commitment, because they need to remain in the organization for external reasons, or because of their moral values (Özdevecioğlu, 2003, p. 115).

In all three dimensions, employee's willingness to stay with the organization is the principle element (Özdevecioğlu, 2003, p. 114). In all three dimensions, while there is a connection between the organization and the employee the quality of the connection differs regarding the dimension. Employee feels committed to their organization as a result of affective commitment because they want to as a result of continuance commitment because they need to or as a result of normative commitment because it is what they should do (Allen \& Meyer, 1990, p. 3).

When the three-component organizational commitment model is taken into consideration, there are five common features shared among all organizational commitment dimensions (Allen \& Meyer, 1990, p. 5):

- They reflect the feelings of the employee.

- They show the relationship between the employee and the organization.

- They affect working behaviors (absence, performance, organizational citizenship behaviors) 
- They affect employees' intentions to leave and the speed at which they complete their work.

- They affect employees' health and prosperity levels.

All three dimensions reduce the possibility of employee leaving work and determine whether they will stay with the organization (Allen \& Meyer, 1990, p. 7).

\section{Purpose}

This study was conducted to analyze the impact of Certified Training Programs on Organizational Commitment by revealing the connection between Certified Training Programs and employees' levels of Organizational Commitment.

\section{Method}

\section{Universe and Sampling}

The universe of this study consists of the employees working in the ICU, emergency department (ER), dialysis unit and transfusion center of the Bolu Public Hospitals Association General Secretariat, Turkey. The current study was conducted in these departments because these units are considered to be special health care units and because the Ministry of Health periodically organizes certified education programs for employees in these units. The sampling method was not used and it was aimed to reach every single employee.

\section{Research Design}

The surveying method was used to gather data for this study. A total of 74 employees were given surveys. Although 72 surveys were returned, 2 were considered invalid. As such, a total of 70 employees' surveys were used. The first part of the survey form solicits respondents' socio-demographic information and the second part reflects their commitment to the organization. A 9-item Organizational Commitment Scale developed by Allen and Meyer (2003) was used. The scale was designed in the form of a 6-point Likert scale whose scoring is as follows; 1: entirely disagree, 2: disagree, 3: somewhat agree, 4: agree, 5: mostly agree, 6: entirely agree. The first 8 questions in the survey form prepared by the researcher were asked to determine the personal traits and certification state of the employee followed by 9 questions whose objective was to determine respondents' affective commitment, continuance commitment and normative commitment. The reliability of the organizational commitment scale was determined by finding Cronbach Alpha coefficient. 


\section{Data Analysis}

Defining statistical methods were used to analyze the data. The research data were analyzed using the statistical software package SPSS for Windows (22.0). KaiserMeyer-Olkin (KMO) and Bartlett tests as well as a factor analysis were applied to the survey questions and calculations concerning the frequency, percentage, average, standard deviation, t-test, correlation and ANOVA were made.

The Hypotheses of our research;

Hypothesis $^{0}$. There is no relation between Certified Training Programs and Organizational Commitment.

Hypothesis $^{l}$. There is a relation between Certified Training Programs and Organizational Commitment.

Alternative hypotheses of our research;

Hipotesis $^{2}$. There is a relation between Affective Commitment and Certified Training Programs.

Hipotesis ${ }^{3}$. There is a relation between Continuance Commitment and Certified Training Programs.

Hipotesis ${ }^{4}$. There is a relation between length of employment and Organizational Commitment.

\section{Results}

\section{Demographical Features}

The first part of the survey includes information on respondent's age, sex, educational background, time spent in the profession, the department in which they are working certification status of their department and length of employment in the department.

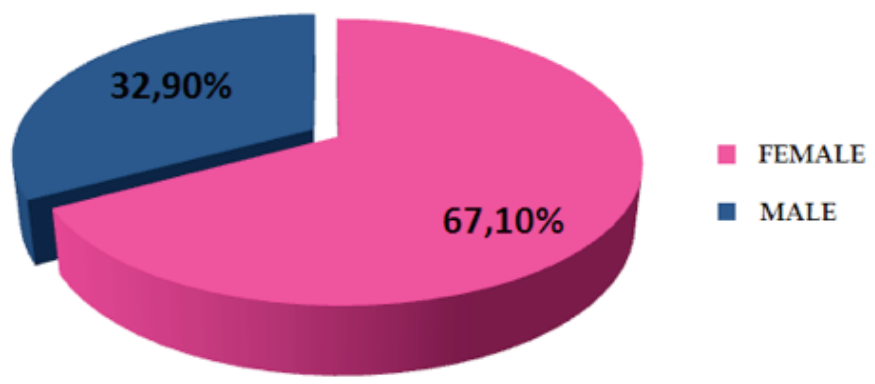




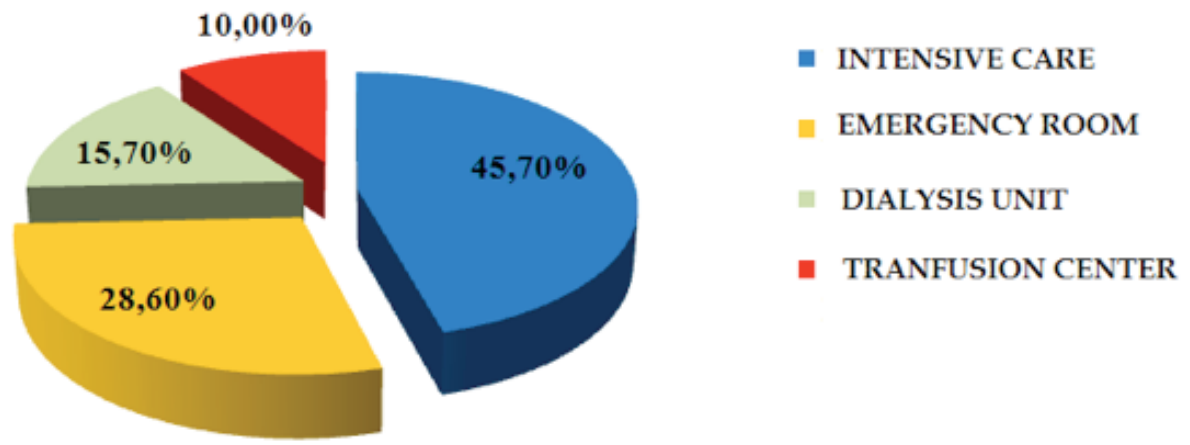

Diagram 2: Status of the research participants according to their departments.

A total of $70(100 \%)$ people participated in the research, (47) $67.10 \%$ of them were female and (23) $32.90 \%$ of them were male.

Among the research participants, (32) $45.70 \%$ worked in the ICU, (20) $28.60 \%$ worked in the ER, (11) $15.70 \%$ worked in the Dialysis Unit and (7) $10.00 \%$ worked in the Transfusion Center.

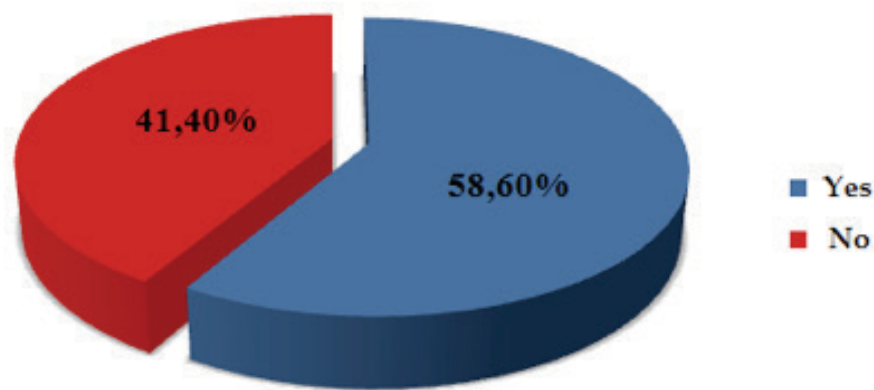

Diagram 3: Participants' certification status within their departments.

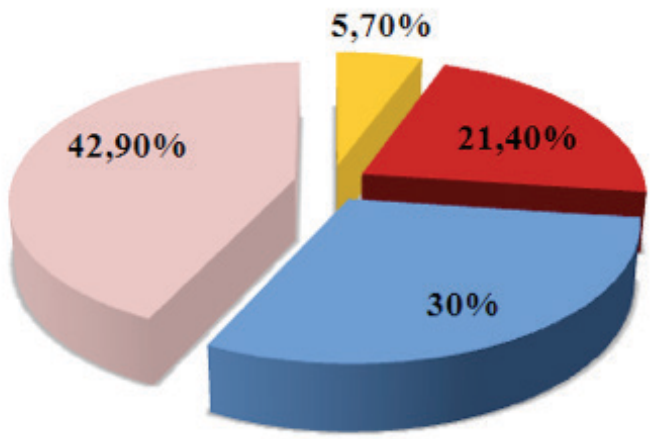

1-3 Years

4-7 Years

8-11 Years

$12+$ Years

Diagram 4: The time participants had spent in the profession. 
Of the total 70 participants, (41) 58.60\% held a certificate related to their department and (29) $41.40 \%$ did not hold a certificate related to their department.

Of the total 70 participants, (30) $42.90 \%$ had spent 12 years or more in their profession, (21) $30 \%$ had spent $8-10$ years, (15) $21.40 \%$ had spent $4-7$ years and (4) $5.70 \%$ had spent $1-3$ years in their profession.

\section{Findings about the Scale Validity}

After the Organizational Commitment survey was adapted into Turkish, 9 items of it were subjected to a trial practice to control for content validity. The scale's structural validity was tested using factor analysis. For this purpose, first the data from the trial practice were checked to see wheter they were adequate for factor analysis. The results from the Kaiser-Meyer-Olkin (KMO) and Bartlett tests showing that the data was adequate to perform a factor analysis are shown in Table 1.

\begin{tabular}{lcc}
\hline Table 1 & & \\
Results of the KMO and Bartlett Test & & .87 \\
\hline Kaiser-Meyer-Olkin Sampling Adequacy Measure & $\mathrm{X}^{2}$ & 455,952 \\
& sd & 36 \\
Bartlett Sphericity Test & $p$ & .000 \\
\hline
\end{tabular}

As seen in the Table 1, the KMO adequacy measurement value was found to be .87. Since this value was found to be above .7, it was accepted as critical. The Bartlett Sphericity Test for the same data was found to be 455.952 and significant by .001 $(\mathrm{X} 236=455.952)$. These values show that it was possible to subject the data obtained from the trial practice to factor analysis. Whether the scale measured more than one concept or variable was found by conducting a Principal Component Analysis and Varimax Rotation. The factor analysis results are as follows.

\begin{tabular}{|c|c|c|c|c|c|c|c|c|c|}
\hline \multicolumn{10}{|c|}{$\begin{array}{l}\text { Table } 2 \\
\text { Results of the Factor Analysis }\end{array}$} \\
\hline \multirow[t]{2}{*}{ Factor } & \multicolumn{4}{|c|}{ Initial Eigen values } & \multicolumn{3}{|c|}{ Total Factor Load } & \multicolumn{2}{|c|}{$\begin{array}{c}\text { After Rotation Total Factor } \\
\text { Load }\end{array}$} \\
\hline & Total & Vary $\%$ & Cluster $1 / 2$ & Total & Vary $\%$ & Cluster $1 / 2$ & Total & Vary $\%$ & Cluster $1 / 2$ \\
\hline 1 & 5.18 & 57.553 & 57.553 & 4.175 & 46.388 & 5.18 & 57.553 & 4.175 & 46.388 \\
\hline 2 & 1.122 & 12.461 & 70.014 & 2.126 & 23.626 & 1.122 & 12.461 & 2.126 & 70.014 \\
\hline 3 & .901 & 10.009 & 80.023 & & & & & & \\
\hline 4 & .770 & 8.552 & 88.575 & & & & & & \\
\hline 5 & .318 & 3.532 & 92.107 & & & & & & \\
\hline 6 & .288 & 3.199 & 95.306 & & & & & & \\
\hline 7 & .173 & 1.927 & 97.232 & & & & & & \\
\hline 8 & .159 & 1.768 & 99.001 & & & & & & \\
\hline 9 & .090 & .999 & 100.00 & & & & & & \\
\hline
\end{tabular}


As seen in Table 2, there two factors with an Eigen value greater than 1. These two factors explain $70.014 \%$ of the variance. The total variance explained by each of the factors after the rotation are $46.388 \%$ and $70.014 \%$, respectively.

On the other hand, analyses conducted using the Varimax Vertical Rotation technique show that the scale has a two-factor structure. Under which factors the items in the survey $\mathrm{f}$

Table 3

Factor Load, $r$ and $t$ Values of the Items

\begin{tabular}{ccccc}
\hline Item No. & 1. Factor & 2. Factor & $\mathrm{r}$ & $\mathrm{T}$ \\
\hline I1 & .87 & & $.81\left(^{* *}\right)$ & $-12.667^{* *}$ \\
I2 & .87 & & $.83(* *)$ & $-12.495^{* *}$ \\
I3 & .90 & & $.87\left(^{* *}\right)$ & $-18.725^{* *}$ \\
I8 & .83 & & $.81\left(^{* *}\right)$ & $-16.695^{* *}$ \\
I9 & .90 & .58 & $.85\left(^{* *}\right)$ & $-13.570^{* *}$ \\
I4 & & .72 & $.34\left(^{* *}\right)$ & $-4.280^{* *}$ \\
I5 & & .66 & $.58(* *)$ & $-6.193^{* *}$ \\
I6 & & .71 & $.57\left(^{* *}\right)$ & $-6.540^{* *}$ \\
I7 & & $.36(* *)$ & $-4.538^{* *}$ \\
\hline
\end{tabular}

significant by $* * p<.01$.

When Table 3 is taken into consideration, items I1, I2, I3, I8 and I9 are seen to fall into the first dimension, and items I4, I5, I6 and I7 into the second dimension, ranked at the highest load value. When the factor loads of the items are analyzed, it is seen that they range between .58 and .90 . These load values indicate that the scale is two dimensional and that every item has the necessary load value to be included in the scale. Among the four factors obtained from the factor analysis, factor 1, composed of 5 items, was named "Affective Commitment" and factor 2, composed of 4 items, was named "Continuance Commitment". Even though Meyer and Allen (2003) separated them into three groups, they are considered under two dimensions in the current study. It is believed that the scale adapted into Turkish showed different sub-dimensions than the original because of differences in culture and perception, on the one hand, and because of different comments from the work group, on the other. Ulukap1 and Bedük (2014) who used the 18-item Organizational Commitment Scale developed by Allen and Meyer (1993) stated, "As a result of the factor analysis on the concept of organizational commitment, items are perceived differently from the generally accepted dimensions and four dimensions have been revealed." Ekinci (2006) used the same 9-item Organizational Commitment Scale developed by Allen and Meyer (2003) used in the current study, expressing that according to the variance explanation rates, there is a factor explaining the Organizational Commitment Survey's questions.

In Table 3, the results of the item analysis based on the scale correlation are presented. The results illustrate that correlation values range between $r=.36$ (I7) and $r=.87$ (I3) and 
are significant by .01. When looking at the correlation values with the measurable features of the scale in general, the following conclusion can be made; every item and the feature that it seeks measured are the same. As a result, every item has the necessary quality to be included in the scale. Furthermore, the $t$ values obtained from the analysis made to compare the average value of respondents' answers in the top $27 \%(n=19)$ and the bottom $27 \%(n=19)$ are significant by .01 . This is important because it shows that every item in the scale is able to differentiate ones with and without the features to be measured.

\section{Findings Regarding the Scale Reliability}

To determine the scale's level of reliability, Cronbach's Alpha internal consistency coefficients for the items that are determined in regards to every dimension and overall scale are shown in Table 4.

\begin{tabular}{lccc}
\hline Table 4 \\
Factors and Alpha Reliability Coefficients for the Whole Scale \\
\hline \multicolumn{5}{l}{ 1. Factor } & 2. Factor & Overall Scale \\
\hline Number of Items & 5 & 4 & 9 \\
Cronbach $\alpha$ & .94 & .68 & .90 \\
\hline
\end{tabular}

According to Table 4, Cronbach's Alpha internal consistency coefficients for Factor 1 is .94 .68 for Factor 2 and .90 for the overall scale. These data show that the internal consistency of both the score of the scale itself in general and that of every factor in the scale are highly reliable.

\section{Average Scores and Standard Deviation Values of the Scale's Sub-Dimensions and of the Overall Scale}

The average and standard deviation values of the scores obtained from the items constituting the scale itself and every dimension can be seen in Table 5.

\begin{tabular}{|c|c|c|c|}
\hline & $N$ & Average* & Standard Deviation \\
\hline Affective Commitment (1. Factor) & 70 & 3.61 & .71 \\
\hline Continuance Commitment (2. Factor) & 70 & 3.18 & 1.36 \\
\hline Overall Scale & 70 & 3.37 & .97 \\
\hline
\end{tabular}

*1-2.4 poor, 2.5-3.4 medium and 3.5-6 good level.

When we look at the Table 5, to evaluate the adequacy levels of the factors in scale, ones with an average score of 1-2.4 can be defined as having a poor level, 2.5-3.4 as having a medium level and 3.5-6 as having a good level.

According to these evaluation criteria, the average score for adequacy in Affective Commitment has a good level (3.61) and the average score for Continuance Commitment 
has a medium level (3.18). When the overall scale is analyzed, the average score for employees' Organizational Commitment was determined to be 3.37 .

\section{$t$-Test results of the Employees' Organizational Commitment Levels According to their Certification Statuses}

The $t$-Test results for the range of the average scores obtained by the answers given to items under the sub-dimensions those for the overall scale regarding whether respondents held some sort of certification or not can be seen in the Table 6 .

\begin{tabular}{|c|c|c|c|c|c|c|c|}
\hline Organizational Commitment & $\begin{array}{c}\text { Certification } \\
\text { Status }\end{array}$ & $\mathrm{N}$ & Average & $\begin{array}{c}\text { Standard } \\
\text { Deviation }\end{array}$ & $t$ & $s d$ & $p$ \\
\hline \multirow{2}{*}{ Affective Commitment } & Yes & 41 & 3.9329 & .70273 & \multirow{2}{*}{5.155} & \multirow{2}{*}{68} & \multirow{2}{*}{.000} \\
\hline & No & 29 & 3.1724 & .43866 & & & \\
\hline \multirow{2}{*}{ Continuance Commitment } & Yes & 41 & 4.1902 & .68695 & \multirow{2}{*}{13.804} & \multirow{2}{*}{68} & \multirow{2}{*}{.000} \\
\hline & No & 29 & 1.7655 & .56838 & & & \\
\hline \multirow{2}{*}{ General Total } & Yes & 41 & 4.0759 & .56133 & \multirow{2}{*}{15,595} & \multirow{2}{*}{68} & \multirow{2}{*}{.000} \\
\hline & No & 29 & 2.3908 & .40567 & & & \\
\hline
\end{tabular}

significant by $* * p<.05$.

When we look at the Table 6 , a significant difference is observed $[t(68)=5.155$, $p<.05]$ about certification status in the "Affective Commitment" dimension. A significant difference is observed $[t(68)=13.804, p<.05]$ about certification status in "Continuance Commitment". As such, it can then be stated that a significant difference $[t(68)=13.804, p<.05]$ exists between respondents' Organizational Commitment scores generally and whether they hold some sort of certification in their field or not. According to the analysis' results, a significant difference exists between the groups' averages. As such;

Hypothesis ${ }^{0}$. "There is no relation between Certified Training Programs and Organizational Commitment." is refuted.

Hypothesis ${ }^{l}$. "There is a relation between Certified Training Programs and Organizational Commitment." is confirmed.

Alternative hypotheses of our research;

Hipotesis ${ }^{2}$. "There is a relation between Affective Commitment and Certified Training Programs." is confirmed.

Hipotesis ${ }^{3}$. "There is a relation between Continuance Commitment and Certified Training Programs." is confirmed. 


\section{ANOVA results regarding Organizational Commitment based on Employment Length in Organization}

The ANOVA results regarding the range of average score respondents gave to Organizational Commitment Survey items and their length of employment can be seen in Table 7.

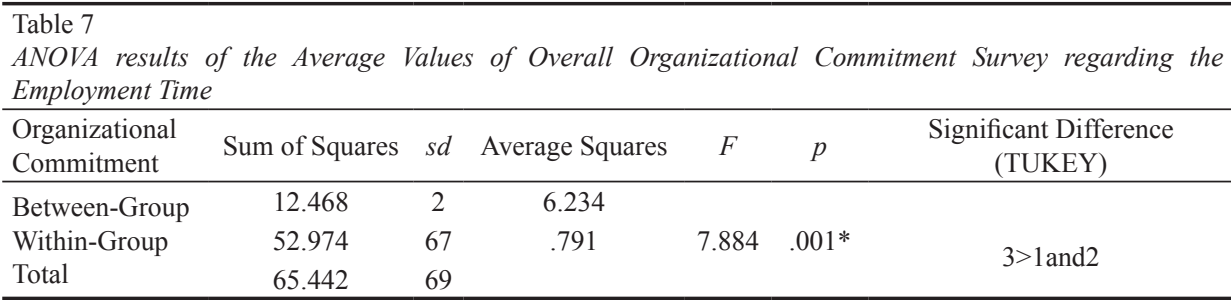

Significant in $* p<.05$. Employment Time: " $1=1-3$ years." " $2=4-7$ years." " $3=8$ years and more"

When we look at Table 7 , a significant difference $[F(2-67)=7.884, p<.05]$ is observed in Organizational Commitment levels in regards to respondents' length of employment in the organization. This significant difference results from the fact that respondents' score averages employed for "8 years and more" (4.02) are higher than those employed for "1-3 years" (3.04) and for "4-7 years" (3.12). According to these data, it can be concluded that the longer one is employed in an organization, the higher one's level of Organizational Commitment is. Thus;

Hipotesis ${ }^{4}$. "There is a relation between length of employment and Organizational Commitment" is confirmed.

\section{Discussion}

The only way for organizations to survive and to be successful in the rapid developing conditions of competition is to have employees who are trained, efficient, coherent with organizational goals and committed to the organization. Businesses realizing that the human factor is the most important factor in organizational success pursue factors affecting employees' organizational commitment levels.

The current study has analyzed the impact of certified training programs on organizational commitment with research having been conducted on the employees working in the Intensive Care Unit, Emergency Room, Dialysis Unit and Transfusion Center of the Bolu Public Hospitals Association General Secretariat, Turkey.

When looking at the conclusions made in this study, it is observed that the organizational commitment, continuance commitment and affective commitment levels of those employees who had participated in a Certified Training Program are higher than those employees who had not obtained any certificates. In this context, it is 
possible to claim that certified education programs play an important role in ensuring organizational commitment in employees. It can be said that certified education programs organized to provide them them with special knowledge and skills within their field develops a sense of responsibility and liability in the employee.

Boylu and Karakaş (2011) stated that work adaptation training is an important element that can be made use of in order to increase organizational commitment. E. Sabuncuoğlu (2007), stated in his study that employees' perception of education activities in their organization increases their organizational commitment and lowers their intent to leave the organization for another. Previously conducted studies determined that education activities are important factors in increasing organizational commitment.

When we look at the analysis of organizational commitment levels regarding employment time, it is seen that there is a vertical positive relation. In other words, the longer one has been employed, the more committed the employee is to his organization.

It is considered that Certified Training Programs, which are an important factor in ensuring organizational commitment, would be advantageous for both employees and organizations if they are up-to-date, open to development and organized periodically. If employees participate in certification programs related to their own department and if these certification programs are turned into periodically repeated Recertification Training Programs, employees will become knowledgeable, productive, committed to organization, and open to innovations, which will then increase the organization's effectiveness and activity, helping them to achieve their goals and targets more easily.

\section{References}

Allen, N. J., \& Meyer, J. P. (1990). The measurement and antecedents of affective, continuance and normative commitment to the organization. Journal of Occupational Psychology, 63, 1-18.

Allen, N. J., \& Meyer, J. P. (1993). Organizational commitment: Evidence of career stage effects. Journal of Business Research, 26, 49-61.

Allen, N. J., \& Meyer, J. P. (2003). Organizational commitment in the military: A discussion of theory and practice. Military Psychology, 15, 237-253.

Boylu, Y., \& Karakaş, A. (2011). İşe alıştırma eğitiminin örgütsel bağlılığa etkisi [The effect of orientation education on organizational commitment]. Ticaret ve Turizm Eğitim Fakültesi Dergisi, 1, 61-75.

Çetin, M. (2004). Ölçüm, örgüt kültürü ve örgütsel bă̆lllık [Measurement, organizational culture and organizational commitment]. Ankara, Turkey: Nobel Yayın.

Davis, K., \& Newstrom, J. W. (1989). Organizational behavior: Human behavior at work (9th ed.). New York, NY: McGraw-Hill.

Deniz, N. (1999). Global eğitim [Global education]. İstanbul, Turkey: Tükmen Kitabevi. 
Ekinci, K. (2006). Örgütsel iletişim ve örgütsel bağlllık arasındaki ilişki [Relationship between organizational communication and organizational commitment]. (Master's thesis, Atatürk University, Erzurum, Turkey). Retrieved from https://tez.yok.gov.tr/UlusalTezMerkezi/

İnce, M., \& Gül, H. (2005). Yönetimde yeni bir paradigma: Örgütsel bağlllık [A new paradigm in management: Organizational commitment]. Ankara, Turkey: Çizgi Kitabevi.

Kaynak, T., Adal, Z., Ataay, İ., Uyargil, C., Sadullah Ö., Acar, A. C., ... Uluhan, R. (2000). İnsan kaynaklarl yönetimi [Human resources management]. İstanbul, Turkey: Dönence Basım.

Koçel, T. (1999). Işletme yöneticiliği, yönetim ve organizasyon, organizasyonlarda davranış: Klasikmodern-çağdaş yaklaşımlar [Business management, management and organization, behavior in organizations: Classical-modern-contemporary approaches] (7th ed.). İstanbul: Beta Basım.

Koçel, T. (2011). İşletme yöneticiliği [Business management]. İstanbul, Turkey: Beta Yayıncılık.

Mercan, M. (2006). Öğretmenlerde örgütsel bă̆lllık, örgütsel yabancılaşma ve örgütsel vatandaşlı [Organizational commitment, organizational alienation and organizational citizenship in teachers] (Master's thesis, Afyon Kocatepe University, Afyonkarahisar, Turkey). Retrieved from https://tez.yok.gov.tr/UlusalTezMerkezi/

Milli Eğitim Bakanlığı. (1983). Aday Memurların Yetiştirilmesine Dair Genel Yönetmelik. 27.06.1983 tarih ve 18090 say1lı Resmi Gazete.

Özdevecioğlu, M. (2003). Algılanan örgütsel destek ile örgütsel bağlılık arasındaki ilişkilerin belirlenmesine yönelik bir araştırma [A study on determining the relationship between perceived organizational support and organizational commitment]. Dokuz Eylül Üniversitesi I.I.I.B.F. Dergisi, 18(2), 113-130.

Penley, L. E., \& Gould, S. (1988). Etzioni's model of organizational involvement: A perspective for understanding commitment to organizations. Journal of Organizational Behavior, 9(1), 15-28.

Sabuncuoğlu, E. (2007). Eğitim, örgütsel bağlılık ve işten ayrılma niyeti arasındaki ilişkilerin incelenmesi [Investigation of relationship between education, organizational commitment and intention to quit the job]. Ege Akademik Bakış, 7(2), 613-628.

Sabuncuoğlu, Z. (1994). Personel yönetimi [Personnel management] (7th ed.). Eskişehir, Turkey: Anadolu Üniversitesi Basımevi.

Schermerhorn Jr, J. R., Hunt, J. G., \& Osborn, R. N. (1994). Managing organizational behaviour (5th ed.). New York, NY: John Wiley \& Sons Inc.

T.C. Sağlık Bakanlığı. (2009). Sağllk Bakanlığl Hizmet İçi Eğitim Yönetmeliği [In-Service education regulation]. 11.12.2009 tarih ve 15296 say1.

T.C. Sağlık Bakanlığı. (2014). Sağlık Bakanlı̆̆ı Sertifikalı Eğitim Yönetmeliği. 04.02.2014 tarih ve 28903 say1.

Tepe, A. (2004). Örgütsel iletişimin örgütsel bă̆lılı̆̆a etkisi [The effect of organizational communication on organizational commitment]. (Master's thesis, Marmara University, Istanbul, Turkey). Retrieved from https://tez.yok.gov.tr/UlusalTezMerkezi/

Ulukapı, H., \& Bedük, A. (2014). Örgütsel adaletin işgörenlerin örgütsel bağl1lık düzeylerine etkisi [The impact of organizational justice on employees' organizational commitment levels]. Uluslararası Sosyal Araştırmalar Dergisi, 7(31), 771-778.

Yıldız, K. (2013). Örgütsel bağlılık ile örgütsel sinizm ve örgütsel muhalefet arasındaki ilişki [The relationship between organizational commitment and organizational cynicism and organizational dissent]. Turkish Studies International Periodical for the Languages, Literature and History of Turkish or Turkic, 8(6), 853-879. 